This PDF is a selection from a published volume from the National Bureau of Economic Research

Volume Title: Trade in Services in the Asia Pacific Region, NBER East Asia Seminar on Economics (EASE), Volume 11

Volume Author/Editor: Takatoshi Ito and Anne O. Krueger, editors

Volume Publisher: University of Chicago Press

Volume ISBN: 0-226-38677-5

Volume URL: http://www.nber.org/books/ito_03-1

Conference Date: June 22-24, 2000

Publication Date: January 2003

Title: Measuring the Cost of Barriers to Trade in Services

Author: Philippa Dee, Kevin Hanslow, Tiem Phamduc

URL: http://www.nber.org/chapters/c10154 


\title{
Measuring the Cost of Barriers to Trade in Services
}

\author{
Philippa Dee, Kevin Hanslow, and Tien Phamduc
}

To what extent can the traditional tools of trade policy analysis be used to analyse the economic costs of barriers to trade in services?

Traditional analysis of trade barriers has focused primarily on the effects of tariffs. These are discriminatory taxes levied on foreign-produced goods at the border of a country.

The Heckscher-Ohlin (HO) framework is a standard framework in which tariffs have been analyzed (Heckscher [1919] 1949; Ohlin 1933). This framework assumes perfect substitutability between domestically produced and foreign goods of the same type, fixed endowments of primary factors of production, and perfect mobility of those factors between sectors within an economy. The framework has been extended to consider more than two goods and factors (Jones and Scheinkman 1977), the presence of a sectorspecific factor of production (Mayer 1974; Mussa 1974), imperfect competition (Markusen 1981), increasing returns to scale (Melvin 1969) and product differentiation (Krugman 1979; Helpman 1981).

However, barriers to trade in services are unlike tariffs. They are typically regulatory barriers, rather than explicit taxes. They need not discriminate against foreigners. Indeed, barriers to market access are often designed to protect incumbent firms from any new entry, be it by domestic or foreign firms. And barriers to services trade are not restricted to affecting the out-

Philippa Dee is assistant commissioner, and Kevin Hanslow is director, at the Productivity Commission, Australia. Tien Phamduc is at the International Business School at Griffith University.

The views expressed in this paper are those of the authors and do not necessarily reflect those of the Productivity Commission. The authors are grateful for early discussions with Anne O. Krueger and comments from Kym Anderson, Chang-Tai Hsieh, Fukunari Kimura, and Will Martin. 
put of services firms. One particularly important category of barriers to services trade-restrictions on foreign direct investment by service firmsaffects the use of primary factors. These restrictions are recognized in the General Agreement on Trade in Services (GATS) under the World Trade Organization (WTO), since this agreement recognizes commercial presence as one of the modes by which services are traded.

To date, few papers of either a theoretical or an empirical nature have reviewed all these aspects of barriers to services trade. Some early papers largely dismissed concerns that the determinants of comparative advantage in services might differ from those in goods (Hindley and Smith 1984; Deardorff 1985). A few theoretical papers in the late 1980s examined some of the important characteristics of services, including knowledge intensity (e.g., Markusen 1989; Melvin 1989). This characteristic also featured in subsequent analysis of goods trade under imperfect competition (e.g., Grossman and Helpman 1991). However, those early theoretical papers did not look at the nature of barriers to services trade. Recently, a few empirical papers have examined the effects of removing barriers to trade in services. Many of these have failed to take account of barriers to commercial presence as an important category of barriers to trade in services (Brown et al. 1995; Brown, Deardorff, and Stern 1996; Hertel 1999; Nagarajan 1999). One seminal paper by Petri (1997) introduced a treatment of barriers to foreign direct investment in the services sector, but it failed to take into account barriers on the other modes of service delivery. Moreover, all empirical papers have suffered from a dearth of convincing empirical estimates of the incidence and economic significance of barriers to services trade.

A recent empirical paper by Dee and Hanslow (2000) sought to analyze the effects of removing barriers to services trade in a more comprehensive fashion. ${ }^{1}$ The barriers included nondiscriminatory barriers to market access as well as discriminatory restrictions on national treatment. They included barriers to commercial presence as well as barriers to the other modes of service delivery. The focus of that paper was to compare the gains from liberalizing services trade with the gains from removing all postUruguay barriers to trade in agriculture and manufacturing. The paper also compared the gains from the total removal of barriers to services trade with the gains from several alternative approaches to partial liberalization. It identified significant second-best problems with some approaches to partial liberalization.

The purpose of this paper is to look more deeply at that analysis of services trade liberalization in order to assess the extent to which the traditional Stolper and Samuelson (1941) and Rybczynski (1955) results from the HO framework are still relevant in a more realistic model of services

1. Brown and Stern (2001) contains a services model that was developed independently and shares a number of conceptual and data features with the model presented here. 
trade liberalization. In the process, the analysis examines whether and how the benefits of services trade liberalization are passed on to other sectors in the economy. Thus, the analysis tries to open up the "black box" of what is a rather complex general equilibrium model of services trade in order to gain insights into the sectoral results from that model in terms of more simple textbook treatments of trade policy analysis.

The structure of the paper is as follows. It first describes the model useda multisector, multiregional computable general equilibrium model of world trade and investment. The theoretical structure of the model covers both foreign direct investment (FDI) and portfolio investment. The model's database contains estimates of FDI stocks and the activities of FDI firms, each on a bilateral basis. Thus, the model recognizes that both goods and services can be delivered via FDI as well as by conventional trade. The paper then looks at the size of the barriers to trade in services and the cost impost they impose on other sectors of the economy. This analysis uses the first of a comprehensive new set of estimates of barriers to services trade. To understand the general equilibrium effects of removing these barriers, the effects on each sector in selected economies are built up from a more restricted, partial equilibrium multicountry model. To this partial model are gradually added the resource constraints and income linkages associated with general equilibrium. It is as the resource constraints are added that the relevance of Stolper-Samuelson and Rybczynski effects can be analysed. The paper then briefly summarizes the implications of services trade liberalization for regional incomes. Finally, the paper identifies areas for further research.

\subsection{The FTAP Model}

The model is a version of the Global Trade Analysis Project model (GTAP; Hertel 1997) with foreign direct investment, known as FTAP. The treatment of FDI follows closely the pioneering work of Petri (1997). The FTAP model also incorporates increasing returns to scale and large-group monopolistic competition in all sectors. This follows Francois, McDonald, and Nordstrom (1995), among others, who adopted this treatment for manufacturing and resource sectors, and Brown et al. (1995) and Markusen, Rutherford, and Tarr (1999), who used similar treatments for services. Finally, FTAP makes provision for capital accumulation and international borrowing and lending. This uses a treatment of international (portfolio) capital mobility developed by McDougall (1993) and recently incorporated into GTAP by Verikios and Hanslow (1999). FTAP is implemented using the GEMPACK software suite (Harrison and Pearson 1996). Its structure is documented fully in Hanslow, Phamduc, and Verikios (1999). The model and its documentation are available at the Productivity Commission website at [http://www.pc.gov.au]. 


\subsubsection{Theoretical Structure}

The FTAP model takes the standard GTAP framework as a description of the location of economic activity and then disaggregates this by ownership. For example, each industry located in Korea comprises Koreanowned firms, along with U.S., Japanese, and other multinationals. Each of these firm ownership types is modeled as making its own independent choice of inputs to production, according to standard GTAP theory, and each firm type has its own sales structure.

On the purchasing side, agents in each economy make choices among the products or services of each firm type, distinguished by both ownership and location, and then among the individual (and symmetric) firms of a given type. Thus, the model recognizes the firm-level product differentiation associated with monopolistic competition. Firms choose among intermediate inputs and investment goods, whereas households and governments choose among final goods and services.

Agents are assumed to choose first among products or services from domestic or foreign locations, with a constant elasticity of substitution (CES) of 5. They then choose among particular foreign locations and among ownership categories in a particular location, both with a CES elasticity of substitution of 10. Finally, they choose among the individual firms of a particular ownership and location, with a CES elasticity of substitution of 15. With firm-level product differentiation, agents benefit from having more firms to choose among, because it is more likely that they can find a product or service suited to their particular needs. Capitalizing on this, Francois, McDonald, and Nordstrom (1995) show that the choice among individual firms can be modeled in a conventional model of firm types (not firms) by allowing a productivity improvement whenever the output of a particular firm type (and hence the number of individual firms in it) expands. However, because the substitutability among individual firms is assumed here to be very high, the incremental gain from greater variety is not very great, and this productivity-enhancing effect is not particularly strong (the elasticity of productivity with respect to output is $1 / 15=0.0667){ }^{2}$

The first two choices, among domestic and foreign locations, are identical to the choices in the original GTAP model. They have been parameterized using values, 5 and 10, that are roughly twice the standard GTAP Armington elasticities. Two reasons can be given for doubling the standard elasticities. One is that only with such elasticities can GTAP successfully reproduce historical changes in trade patterns (Gehlhar 1997). The other is

2. The equivalent elasticity of productivity with respect to inputs is $0.0667 /(1-0.0667)=$ 0.0714, where this latter concept is used by Francois, McDonald, and Nordstrom (1995). The elasticities of productivity with respect to output and inputs are not equal because of the assumption of increasing returns to scale. Another reason that scale effects are not strong is that, with this nested structure, the economies of scale are regional rather than global. 
that higher elasticities accord better with notions of firm-level product differentiation. Further calibration of the model to historical data using methods of maximum entropy (e.g., Liu, Arndt, and Hertel 2000) may provide a feasible means of refining the above estimates of firm-level substitution possibilities in the future.

The order of the first three choices, among locations and then among ownership categories, is the opposite of the order adopted by Petri (1997). The current treatment assumes that from a Korean perspective, for example, a U.S. multinational located in Korea is a closer substitute for a Korea-owned firm than it is for a U.S. firm located in the United States. Petri's treatment assumes that United States-owned firms are closer substitutes for each other than for Korean firms, irrespective of location.

There are two reasons for preferring the current treatment.

The first is that Petri's treatment produces a model in which multilateral liberalization of tariffs on manufactured goods produces large economic welfare losses, for most individual economies and for the world as a wholean uncomfortable result at odds with conventional trade theory. The reason for the result is spelled out in more detail in Dee and Hanslow (2000).

The second reason for preferring the current treatment is that, in many instances, it accords better with reality. One of the distinguishing characteristics of services is that they are tailored each time to meet the needs of the individual consumer. Another characteristic is that they are often delivered face-to-face, sometimes making commercial presence (through FDI) the only viable means of trade. These characteristics taken together mean that service firms in a given location, irrespective of ownership, will tailor their services to meet local tastes and requirements and, thus, appear to be close substitutes, as in the current treatment.

Whereas the demand for the output of firms distinguished by ownership and location is determined as above, the supply of FDI is determined by the same imperfect transformation among types of wealth as in Petri (1997). Investors in each economy first divide their wealth between "bonds" (which can be thought of as any instrument of portfolio investment), real physical capital, and land and natural resources in their country of residence. This choice is governed by a constant elasticity of transformation (CET) semielasticity of 1 , meaning that a 1 percentage point increase in the rate of return on real physical capital, for example, would increase the ratio of real physical capital to bond holdings by 1 percent. A bond is a bond, irrespective of who issues it, implying perfect international arbitrage of rates of return on bonds. However, capital in different locations is seen as different things. Investors next choose the industry sector in which they invest (with a CET semi-elasticity of 1.2). They next choose whether to invest at home or overseas in their chosen sector (with a CET semi-elasticity of 1.3). Finally, they choose a particular overseas region in which to invest (with a CET semi-elasticity of 1.4). 
The less-than-perfect transformation among different forms of wealth can be justified as reflecting some combination of risk aversion and lessthan-perfect information. It is important to note, however, that although the measure of economic welfare in FTAP currently recognizes the positive income contribution that FDI can make, it does not discount that for any costs associated with risk taking, given risk aversion. This is an important qualification to the current results and will be the subject of further research.

Although the chosen CET parameters at each "node" of the nesting structure may appear low, the number of nests means that choices at the final level (across destinations of FDI) are actually very flexible. For example, it can be shown that, holding total wealth fixed but allowing all other adjustments across asset types and locations to take place, the implied semielasticity of transformation between foreign destinations can easily reach 20 and can be as high as 60 . The variation across regions in these implied elasticities comes about because of the different initial shares of assets in various regional portfolios.

The choice of CET parameters at each node was determined partly by this consideration of what they implied for the final elasticities, holding only total wealth constant. They were also chosen so that this version of FTAP gave results that were broadly comparable to an earlier version of GTAP with imperfect international (portfolio) capital mobility, for experiments involving the complete liberalization of agricultural and manufacturing protection (Verikios and Hanslow 1999). Imperfect capital mobility was also a feature of the GTAP-based examination of Asia-Pacific Economic Cooperation (APEC) liberalization by Dee, Geisler, and Watts (1996) and Dee, Hardin, and Schuele (1998). These parameters thus provide a familiar starting point from which refinements could be made in the future, possibly based on methods of maximum entropy.

In one respect, however, the current version of FTAP does differ from previous versions of GTAP with imperfect capital mobility. The GTAP variants assumed that capital was perfectly mobile across sectors, whereas FTAP has less-than-perfect sectoral mobility. Furthermore, the choice of sector is relatively early in the nesting structure, so that the implied elasticities guiding choice of sector, holding only total wealth constant, are relatively low (e.g., 1.2 in the United States). As a result, FTAP tends to exhibit the behavior that resources move less readily between sectors in a given region but more readily across regions in a given sector, although the differences are not dramatic. The current treatment is consistent with the idea that the knowledge capital often required to succeed in FDI, despite the difficulties of language and distance, is likely to be sector specific.

Petri's model assumed that total wealth in each region was fixed. In FTAP, although regional endowments of land and natural resources are fixed (and held solely by each region's residents), regional capital stocks can accumu- 
late over time, and net bond holdings of each region can adjust to help finance the accumulation of domestic and foreign capital by each region's investors. The treatment of capital accumulation follows the original treatment of McDougall (1993) and was also used by Verikios and Hanslow (1999); Dee, Geisler, and Watts (1996); and Dee, Hardin, and Schuele (1998).

With this treatment of capital accumulation, FTAP provides a long-run snapshot view of the impact of trade liberalization, ten years after it has occurred. To the extent that liberalization leads to changes in regional incomes and saving, this will be reflected in changes to the capital stocks that investors in each region will have been able to accumulate. As noted, investors in each region are not restricted to their own saving pool in order to finance capital investment. They may also issue bonds to help with that investment, but only according to their own preferences about capital versus bond holding, and only according to the willingness of others to accept the additional bonds.

\subsubsection{Model Database}

The starting point for FTAP's database was not the standard GTAP database, because this includes measures of trade and investment barriers that are still to be eliminated under the Uruguay Round agreement. Instead, the starting point was an updated version of the GTAP database, following a simulation in which the barriers yet to be eliminated under the Uruguay Round had been removed. Such a database was provided by the work of Verikios and Hanslow (1999), under their assumption of less-than-perfect capital mobility.

\section{Foreign Direct Investment Data}

The Petri treatment of FDI requires the addition of data on bilateral FDI stocks and on the activity levels and cost and sales structures of FDI firms. The methods used to estimate such data were similar to those of Petri. Both APEC (1995) and United Nations (1994) provided limited data on FDI stocks by source, destination, and sector. These data were fleshed out to provide a full bilateral matrix of FDI stocks by source, destination, and sector, using RAS methods (Welsh and Strzelecki 2000). Thus, the individual bilateral estimates may be unreliable, although the more aggregate data match published totals. The resulting estimates are summarized in Dee and Hanslow (2000). The data were collected (and the model implemented) for nineteen regions and three broad sectors. The three sectors - primary (agriculture, resources, and processed food), secondary (other manufacturing), and tertiary (services) - correspond broadly to the three areas of potential trade negotiation in a new trade round. The intention is to use similar methods to produce a model with greater sectoral detail in the future.

One problem with such FDI data is that they distinguish FDI from portfolio investment according to whether the investor (or investing firm) has an 
equity interest of 10 percent or more. This ownership share may not be sufficient to ensure control of an enterprise. ${ }^{3}$ For some purposes, researchers have instead considered affiliates that are majority owned-in which the combined ownership of those persons individually owning 10 percent or more from a particular country exceeds 50 percent. In the current context, a better approach in the future may be to recognize explicitly the size of the equity stake that different countries (including the local host) have in an enterprise, especially since some barriers to services trade are explicitly designed to control the extent of foreign ownership. This is an area for further research.

The FDI stock data were used in turn to generate estimates of the output levels of FDI firms. To do this, we estimated capital income flows by multiplying the FDI stocks by rates of return. These capital rentals were then grossed up to get an output estimate for FDI firms, using ratios of capital rentals to output from the GTAP database. Again, the resulting estimates are similar to those in Petri (1997) and are summarized in Dee and Hanslow (2000). A possible future refinement would be to use additional information on the ratio of value added to output from U.S. and Japanese data on the activities of offshore affiliates (e.g., Baldwin and Kimura 1998; Kimura and Baldwin 1998). Petri (1997) shows how estimates obtained using different methods can differ, sometimes widely. Nevertheless, experience shows that models such as these are more sensitive to estimates of the extent of barriers to services trade than they are to estimates of the underlying services trade and FDI flows.

The detailed cost and sales structures of FDI firms were assumed to be the same as for locally owned firms and were obtained by prorating the GTAP database. A subject for future research would be to make use of information on the true cost and sales structures of FDI firms, again using available U.S. and Japanese data on the activities of offshore affiliates.

\section{Estimates of Barriers to Services Trade}

Estimates of existing barriers to services trade were injected into the model's database, using the techniques of Malcolm (1998). The process is documented in Hanslow et al. (2000).

The estimates of barriers to services trade were the first of a comprehensive new set of estimates, documented in Findlay and Warren (2000). The general methodology of these studies is as follows.

- Qualitative information on barriers to services trade is converted to a quantitative index measure of trade restrictiveness, based on coverage

3. Another potential problem is that two or more countries can treat that same firm as a foreign affiliate. Although in some contexts this can lead to double counting, in the current context it does not because the FDI stock data have not been "grossed up" to account for other owners (which could also include local joint venture partners). 
and some initial judgments about the relative restrictiveness of the different sorts of restrictions.

- An econometric model is developed to measure the determinants of the economic performance (e.g., price, profit margin, cost, or quantity) of service firms in a given sector in different countries, taking account of all the factors that economic theory would suggest are relevant, including the index measure of trade restrictiveness.

- The economic model is used to estimate the determinants of economic performance. Wherever possible, the components of the trade restrictiveness index are entered separately so that the econometrics can reveal something about the relative weights attached to the separate components. $^{4}$

- The results of the econometrics are used to calculate the effect of trade restrictions on performance. Where necessary, quantity or profit effects are converted to price or cost effects.

Estimates of barriers to trade in banking services along these lines were taken from Kaleeswaran et al. (2000), and estimates of barriers to trade in telecommunications services were taken from Warren (2000). The rates can be taken as indicative of post-Uruguay rates, because although the Uruguay Round established the architecture for services trade negotiations, it did not achieve much in the way of services trade liberalization (Hoekman 1995).

For modelling purposes, the barrier estimates were decomposed according to a two-by-two classification.

- The GATS framework distinguishes four modes of service delivery: via commercial presence, cross-border supply, consumption abroad, and the presence of natural persons. Accordingly, the FTAP model distinguishes barriers to establishment from barriers to ongoing operation. This is similar to the distinction between commercial presence and other modes of delivery, because barriers to establishment are a component of the barriers to commercial presence. Barriers to establishment are modeled as taxes on the movement of capital. Barriers to ongoing operation are modeled as taxes on the output of the serviceproviding firms.

- The GATS framework also distinguishes restrictions on market access from restrictions on national treatment. As noted above, the former are restrictions on entry, be it by locally owned or foreign-owned firms. In the FTAP model, they are treated as nondiscriminatory. Restrictions on national treatment mean that foreign-owned firms are treated less favorably than domestic firms. These restrictions are treated as discriminatory.

4. This is not possible where there is high multicollinearity between the various components, or where there is a lack of in-sample variation in some of the components. 
Table 1.1

Classifying Barriers to Trade in Banking and Telecommunications Services

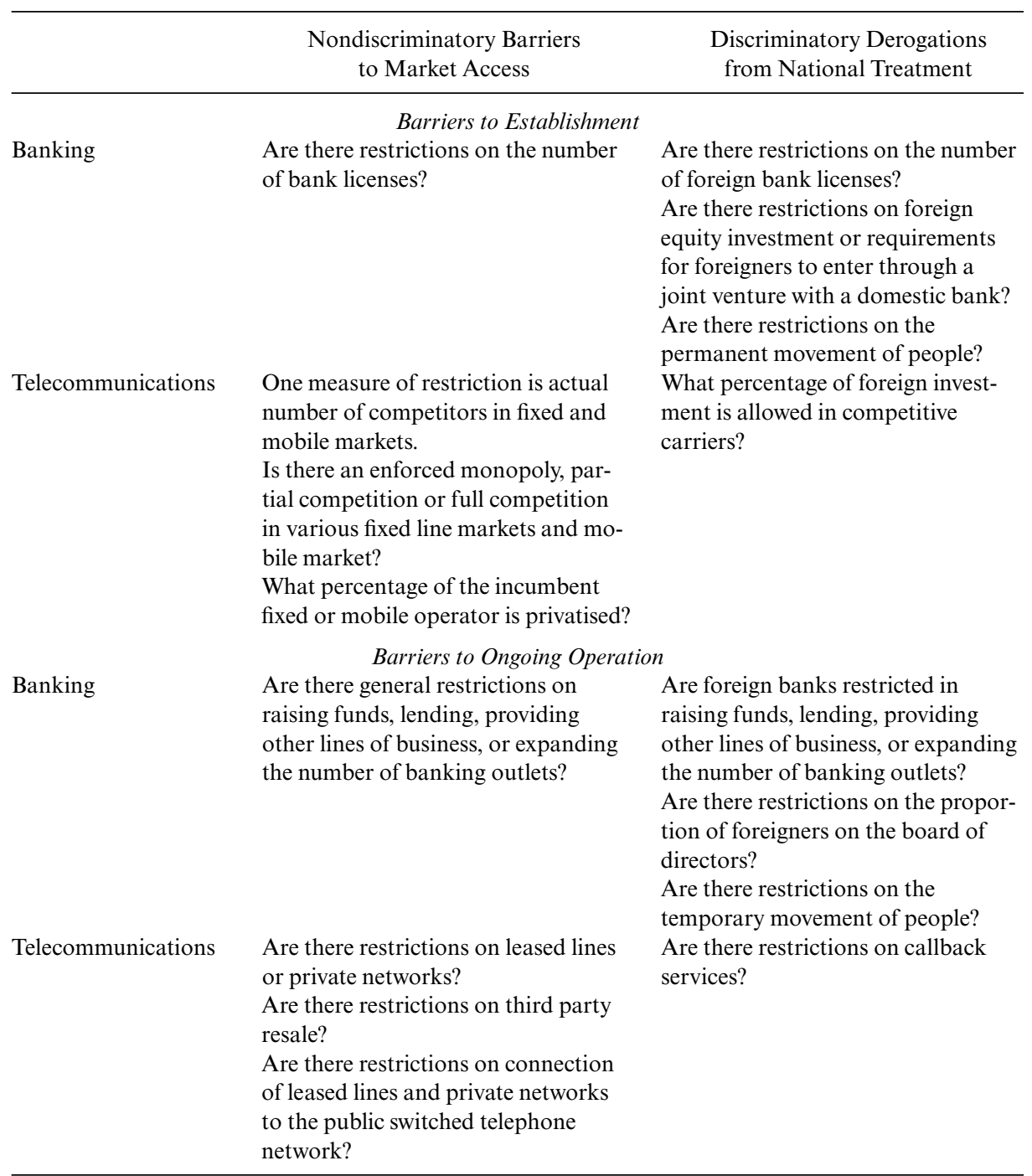

Source: McGuire and Schuele (2000) and Warren (2000).

The decomposition of trade barriers into this two-by-two classification follows the classifications used by Kaleeswaran et al. (2000) and Warren (2000). Table 1.1 shows how they classify barriers to trade in banking and telecommunications services. Note that in the banking sector, prudential regulations were not counted as trade barriers or included in the restrictiveness index. This was based on the recognition that they are designed to address a genuine market failure and the judgment that they are generally 
implemented in an appropriate fashion to that end. It is also consistent with the so-called "prudential carve-out" allowed for in the GATS.

Note also that in the banking study, horizontal (i.e., not sector-specific) restrictions on the permanent movement of people were counted as a barrier to establishment, and hence they were modeled as a barrier to the movement of capital. More properly, these restrictions should be modeled as a barrier to the movement of labor, but so far FTAP does not allow for international labor mobility. Similarly, horizontal restrictions on the temporary movement of people were counted as a barrier to ongoing operation, affecting both offshore affiliates and services delivered via "cross-border" trade, where the latter is broadly defined to include services delivered via the temporary movement of the consumer or the producer. In reality, the barriers affecting true cross-border trade are sufficiently different from those affecting trade involving temporary movement to warrant modeling them separately. These are areas for further research.

A simple average of the estimated price effects of barriers to trade in banking and telecommunications was taken as being typical of most services - all of the GTAP service categories of trade and transport; finance, business, and recreational services; and half of public administration, defense, education, and health. The remainder of public administration, defense, education, and health, along with electricity, water and gas, construction, and ownership of dwellings were assumed to be strictly nontraded (note that engineering services are part of business services, not construction). The resulting average estimates of barriers to trade in the tertiary sector would have been about 50 to 100 percent bigger had the banking and telecommunications estimates been taken as indicative of the whole of the services sector. A procedure for future research is to use the next version of the GTAP database, which will have more services-sector detail, to model barriers to each service separately, thus overcoming the extreme arbitrariness of these assumptions. In the meantime, the computational results should be treated as preliminary and interpreted with appropriate caution.

The resulting structure of post-Uruguay barriers to trade in services is summarized in table 1.2. Barriers to trade in primary (agricultural, resource, and processed food) and secondary (manufacturing) products are also shown for comparison purposes. Barriers to primary products are represented via a combination of taxes on imports, and subsidies (shown in table 1.2 as negative taxes) on exports and output. Unfortunately, at FTAP's threesector level of aggregation, the actual taxes on primary exports and output are a combination of subsidies used for protective purposes, and taxes (e.g., excises on alcohol and tobacco) used for revenue raising. (Although the average taxes on primary output are not shown in table 1.2 , they are all relatively small and mostly positive.) In future, using a database with greater sectoral detail will reduce the problems associated with "aggregation bias."

In the services sector, as noted above, barriers to establishment have been 


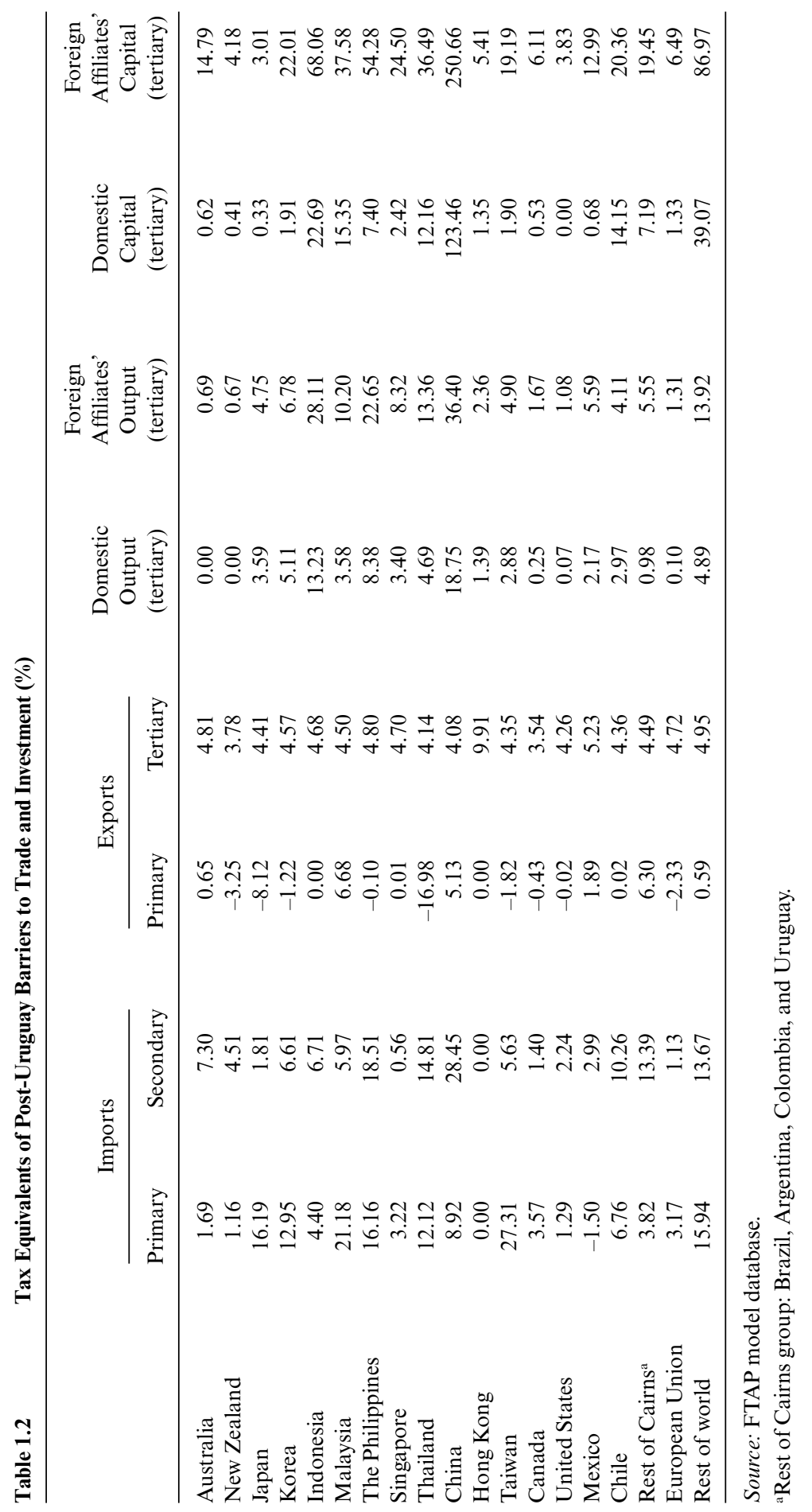


modeled as taxes on capital. Barriers to ongoing operation may affect either FDI firms or those supplying via the other modes and have been modeled as taxes on the output of locally based firms (either domestic or foreign owned) and taxes of the same size on the exports of firms supplying via the other modes, respectively. The estimates of export taxes on services in the fourth column of table 1.2 are trade-weighted averages of the taxes on exports to particular destinations, where these are equal in turn to the taxes on foreign affiliates' output in the destination region, shown in the sixth column. These are modeled as taxes in the exporting region, rather than as tariffs in the importing region, to allow the rents created by the barriers to be retained in the exporting region. The issue of rents is addressed in more detail shortly.

The model also distinguishes restrictions on market access from restrictions on national treatment. The taxes on domestic capital and domestic output in table 1.2 represent the effects of restrictions on market access (affecting establishment and ongoing operation, respectively). The taxes on the capital and output of foreign affiliates are higher than the corresponding taxes on domestic firms, because they represent the effects of restrictions on both market access and national treatment.

The estimates in table 1.2 indicate that barriers to trade in services are generally at least as large as those on agricultural and manufactured products. Most economies have at least some significant barriers to trade in services. The only regions where barriers are low across the board are New Zealand, Japan, Hong Kong, Canada, the United States, and the European Union. However, this statement should be heavily qualified, because it is based only on estimates of barriers to banking and telecommunications. In the same vein, the estimates of overall barriers to services trade for China are very high, because the estimates of barriers to telecommunications services in China are particularly high, as they are in a number of other lowincome developing economies. Estimates based on a broader set of services sectors are likely to produce less variation in overall estimates of services trade barriers across economies.

Barriers to trade in services have been modeled as tax equivalents that generate rents - a markup of price over cost — rather than as things that raise costs above what they might otherwise have been (e.g., Hertel 1999; Brown and Stern 2001). This decision was based on the way in which the price impacts of barriers to trade in banking and telecommunications services were measured. Kaleeswaran et al. (2000) measured the effects of trade restrictions on the net interest margins of banks, a direct measure of banks' markup of price over cost. ${ }^{5}$ Warren (2000) measured the effects

5. Net interest margins - a measure of the difference between borrowing and lending rates of interest - can also be thought of as the "price" of financial intermediation services. The econometric model used to test the significance of barriers to trade in banking services was developed from an economic model of financial intermediation. 
of trade restrictions on the quantities of telecommunications services delivered, and these were converted to price impacts using an estimate of the elasticity of demand for telecommunications services. Thus, Warren's estimates did not provide direct evidence of a markup of price over cost, but the relative profitability of telecommunications companies in many countries suggests that some element of rent may exist. By contrast, there is evidence that trade restrictions in sectors such as aviation raise costs (Johnson et al. 2000). As estimates of the effects of trade barriers in these sectors are incorporated into the model, it will be appropriate to treat some restrictions as cost-raising rather than as rent-creating.

One important implication of the current treatment is that welfare gains from liberalizing trade in services are likely to be understated, perhaps significantly. If trade restrictions create rents, then the allocative efficiency gains from trade liberalization are the "triangle" gains associated with putting a given quantum of resources to more efficient use. By contrast, if trade restrictions raise costs, the gains from trade liberalization include "rectangle" gains (qualified by general-equilibrium effects) from lower costs, equivalent to a larger effective quantum of resources for productive use.

Because barriers to services trade appear to be significant, and because they have been modeled as taxes, the rents they generate will be significant. A key issue is whether those rents should be modeled as being retained by incumbent firms, appropriated by governments via taxation, or passed from one country to another by transfer pricing or other mechanisms. In FTAP, the rents on exports have been modeled as accruing to the selling region, and those on FDI have been modeled as accruing to the region of ownership, after the government in the region of location has taxed them at its general property income tax rate. Despite this, the asset choices of investors are modeled as being driven by pretax rates of return. This is because many economies, in the developed world at least, have primarily destinationbased tax systems. For example, if tax credits are granted for taxes paid overseas, investors are ultimately taxed on all income at the owning region's tax rate. Although such tax credits have not been modeled explicitly, their effect has been captured by having investors respond to relative pretax rates of return. Nevertheless, investor choices are also assumed to be determined by rates of return excluding any abnormal rent component. Investors would like to supply an amount of capital consistent with rates of return including abnormal rents, but they are prevented from doing so by barriers to investment. The amount of capital actually supplied is, therefore, that amount that investors would like to supply at rates of return excluding abnormal rents.

Thus, a portion of the rent associated with barriers to services trade is assumed to remain in the region of location in the form of property income tax revenue, whereas the remainder accrues to the region of ownership. Thus, liberalization of services trade could have significant income effects 
in both home and host regions as these rents are gradually eliminated. Dee and Hanslow (2000) show in detail how significant these effects are, relative to the allocative efficiency effects and other effects normally associated with trade liberalization.

A final point to note is that the model's database does not contain estimates of barriers to investment in agriculture and manufacturing, even though they are likely to be significant. It is unlikely that a new trade round would include negotiations on them. Nevertheless, their omission will affect the model's estimates of the effects of liberalization elsewhere, and the results need to be qualified accordingly.

\subsection{The Cost Impact of Barriers to Trade in Services}

Table 1.2 shows that the direct "tax equivalents" of barriers to trade in services are often significant, compared with the trade barriers expected to remain in agriculture and manufacturing after full implementation of the Uruguay Round. It also shows that barriers to services trade tend to be much higher in developing than in developed economies.

A priori, this does not mean that the services sectors in developing economies would suffer most from services trade liberalization. Because barriers to services trade are unlike tariffs, there are two key mechanisms by which the services sectors in developing countries could expand following services trade liberalization.

- Not all services trade barriers discriminate against foreign services suppliers, so the services sector could expand because of new domestic entry.

- Some services trade barriers restrict inward FDI, so the services sector could expand because of new foreign entry.

These mechanisms could be sufficient to offset the traditional mechanisms by which a protected sector can be harmed by removal of protection.

- Some services barriers discriminate against foreign services delivered cross-border, so the services sector could contract in the face of additional import competition.

- Services trade liberalization may benefit downstream using industries, and the services sector may lose out in the competition for domestic resources (e.g., labor).

Figure 1.1 examines the extent to which downstream using industries are likely to benefit from services trade liberalization. It shows the direct and indirect cost impost of domestic barriers to trade in services on all sectors in selected model regions, as calculated from the FTAP model database.

In general terms, the figure shows the direct and indirect input requirements needed to produce a unit of final demand in each sector. For example, 
A

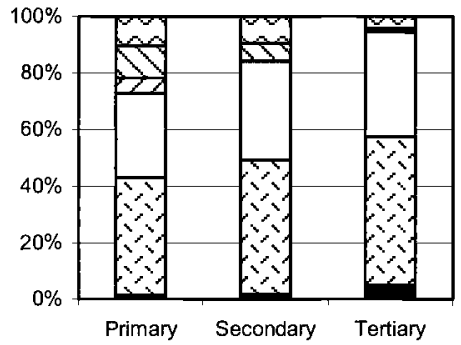

C

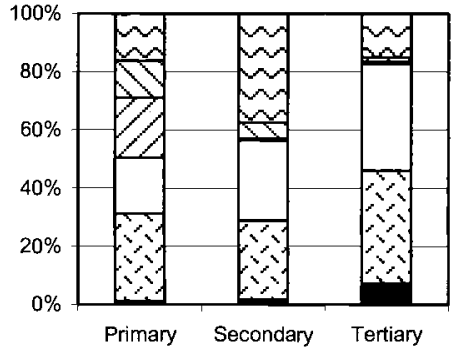

E

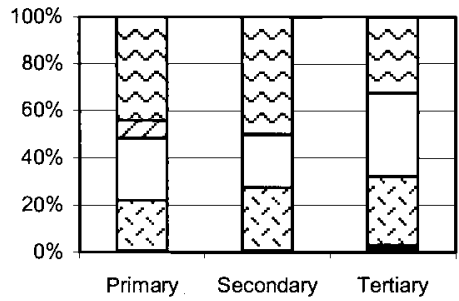

B

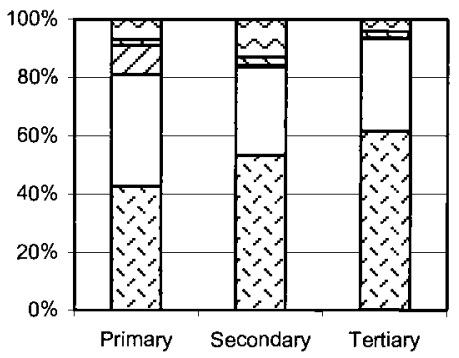

D

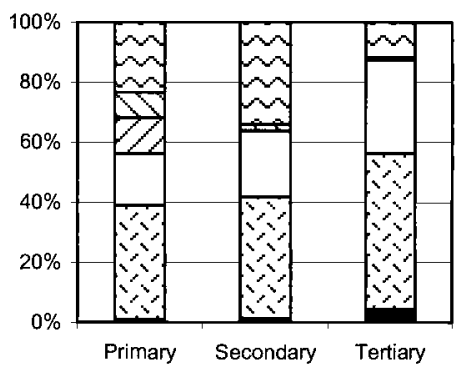

Fig. 1.1 Direct and indirect input requirements per unit of final demand: $A$, Japan; $B$, the United States; $C$, Korea; $D$, Taiwan; $E$, Hong Kong; $F$, Indonesia; $G$, Malaysia; $H$, the Philippines; I, Singapore; $J$, Thailand; $K$, China

a unit of processed food (a primary activity) sold to households might require inputs of unprocessed food (another primary activity), as well as packaging materials from the secondary sector. The packaging materials might again require inputs from forestry (a primary activity), along with electricity from the tertiary sector. Each of these direct and indirect inputs would have its own requirements for labor, capital, fixed factors (land and natural resources), and imported inputs, and these can be added up. Where 

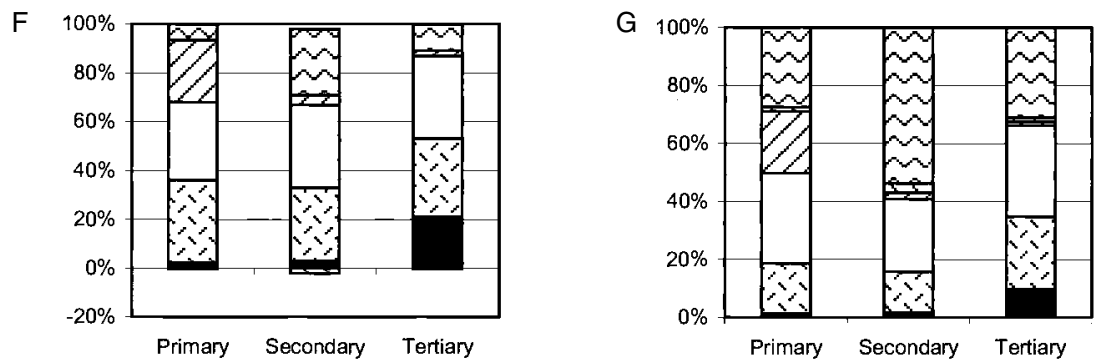

$\mathrm{H}$
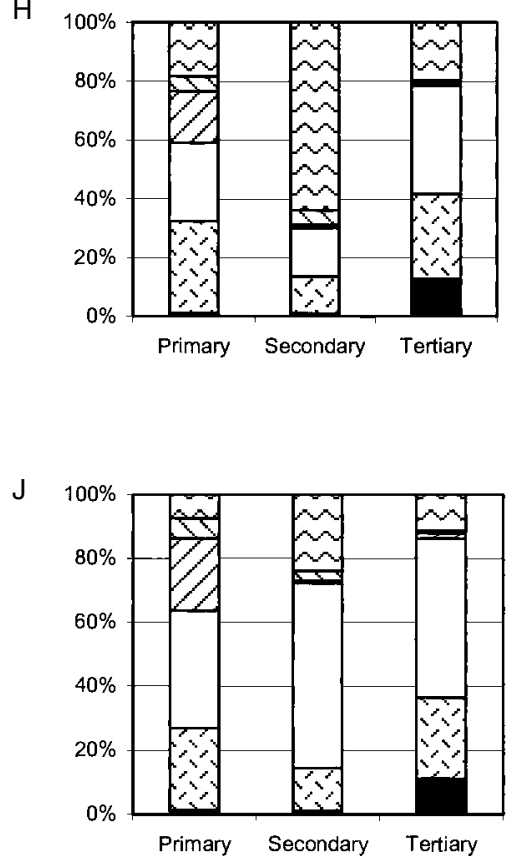
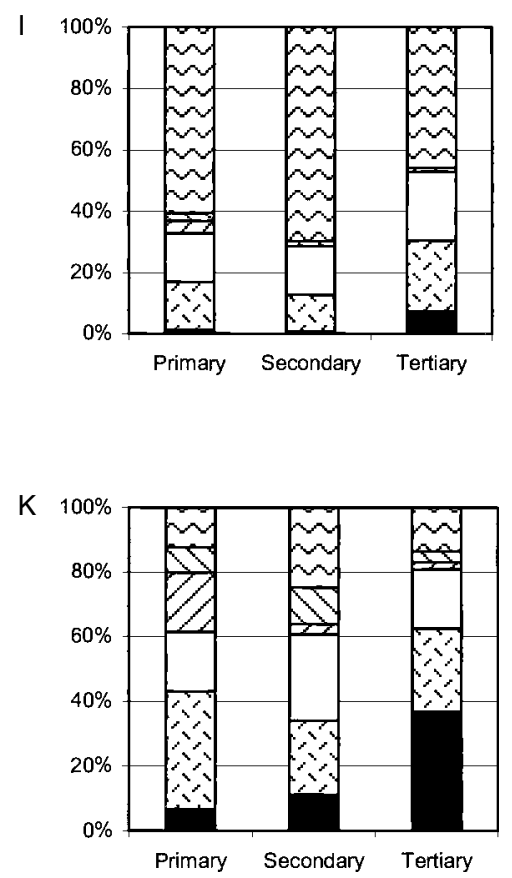

Fig. 1.1 (cont.)

the cost of the direct and indirect inputs is inflated by taxes, the direct and indirect tax contributions can also be calculated.

Thus, the direct and indirect cost impost of domestic barriers to services trade has been calculated by adding together the following:

- the output and capital taxes on direct and indirect services inputs, where those taxes represent the effects of domestic barriers to commercial presence (both establishment and ongoing operation); and

- the export taxes in the source region falling on direct and indirect im- 
ported inputs, where these export taxes represent the effects of domestic barriers to cross-border services trade (where the term cross-border is interpreted loosely to include services traded via the temporary movement of the producer or consumer).

All other domestic taxes are collected in the contribution of "Other taxes," and all other taxes on imports (primarily tariffs) are included with the contribution of "Imports."

Figure 1.1 shows that, in every region shown, the greatest unit cost impost from services trade barriers falls on the services sector itself. This reflects two factors. First, the services sector experiences a direct taxing effect, whereas in other sectors the burden is indirect, through the higher cost of service inputs. Second, this effect is reinforced by the fact that in both developed and developing economies, the services sector itself tends to have a higher direct services input requirement than any other sector. Although other sectors may need service inputs, the greatest intensity of use of services is within the services sector itself. Thus, as will be seen, the benefits of services trade liberalization in many economies are concentrated within the services sector. This result is contrary to the normal effects of tariff removal, where the benefits are typically concentrated in other sectors.

Another feature of figure 1.1 is that in the economies with the highest per capita incomes (Japan, the United States, Korea, Taiwan, and Hong Kong), the cost impost of domestic services trade barriers on other sectors is minimal. Although these economies tend to be more service dependent, in terms of having higher direct service input requirements, their domestic barriers to services trade are also relatively low.

Somewhat surprisingly, in the economies with the lowest per capita incomes (Indonesia, Malaysia, the Philippines, Singapore, Thailand, and China), the cost impost of domestic services trade barriers on other sectors is not much greater. Only in China, where services trade barriers are particularly high, does the cost impost on other sectors approach 10 percent. ${ }^{6}$

By showing the cost impost of only domestic barriers to trade in services, figure 1.1 understates the potential first-round impact of multilateral liberalization of services trade. When barriers are removed globally, not only will domestic goods and services be cheaper, but so too will goods and services available in other economies. This benefit is likely to be significant in the highly import-intensive economies such as Korea, Taiwan, Hong Kong, Malaysia, the Philippines, and Singapore. Moreover, because the trade and transport services used to ship goods internationally will also be

6. The cost impost is estimated to be particularly high in China because its telecommunications market is particularly restrictive. When estimates of services barriers are incorporated for a broader range of services than banking and telecommunications, the overall cost imposts could differ from those shown here. Not only could the overall impost in China be lower, but the impost in developed countries could also be higher (since banking and telecommunications happen to be sectors in which developed countries are particularly liberal). 
cheaper, there will be an additional cost reduction effect not captured in figure 1.1.

\subsection{The Sectoral Effects of Removing Barriers to Trade in Services}

\subsubsection{Partial Equilibrium Effects on Sectoral Output}

A useful way to understand the sectoral effects of removing barriers to trade in services is to start with a partial equilibrium framework and to gradually add the economy-wide constraints that distinguish a general from a partial equilibrium approach. This is a very useful technique of analysis, developed by Hertel (1997).

An initial partial equilibrium model is obtained by "turning off" the following parts of FTAP:

- Factor supply constraints. Each sector in each region can get all the labor and capital it needs at the going wage or rental price. Thus, the secondary and tertiary sectors in each region have horizontal supply curves (which nevertheless move downward as services barriers are removed). The primary sector continues to have an upward-sloping supply curve because fixed factors (land and natural resources) are still treated as being in fixed supply in each economy.

- Income linkages. Irrespective of what is projected to happen to factor prices and other variables, the model's measure of welfare is held fixed in each region. This "equivalent variation" is essentially a measure of net national product, or the real income accruing to the residents of each economy. In general equilibrium, it is affected not just by the amount of activity generated within a region, but also by net foreign interest and dividend payments associated with foreign borrowing and lending and with FDI.

- The endogenous productivity and taste changes associated with a love of variety. (In the full FTAP model, firms benefit from a wider choice of intermediate inputs in the same way that consumers benefit from a wider choice of final goods.)

In partial equilibrium, all the demand-side substitution possibilities of the full FTAP model are still in operation. Thus, for example, the demand for the output of the secondary sector in a region will depend on the following factors:

- how the cost (and hence price) of its output changes relative to the cost (and price) of output of secondary sectors in other economies, and how consumers and users in each region substitute between domestic and various imported sources of secondary output as a result of those relative price changes; 
Table 1.3

Partial Equilibrium Effects on Selected Regions of Removing Global Barriers to

Trade in Services, by sector (\%)

\begin{tabular}{|c|c|c|c|c|c|c|c|c|c|}
\hline & \multicolumn{3}{|c|}{ Primary } & \multicolumn{3}{|c|}{ Secondary } & \multicolumn{3}{|c|}{ Tertiary } \\
\hline & $\mathbf{Q}$ & $\mathrm{Pd}$ & $\mathrm{Pm}$ & $\mathbf{Q}$ & $\mathrm{Pd}$ & $\mathrm{Pm}$ & $\mathbf{Q}$ & $\mathrm{Pd}$ & $\mathrm{Pm}$ \\
\hline Japan & -0.3 & -2.4 & -0.9 & -1.4 & -2.6 & -3.9 & -3.4 & -2.1 & -21.9 \\
\hline United States & -1.3 & -0.7 & -1.3 & -7.3 & -0.6 & -3.3 & -4.3 & -0.4 & -13.6 \\
\hline Korea & -0.1 & -1.9 & -1.0 & 2.3 & -2.9 & -3.1 & -2.3 & -3.5 & -16.3 \\
\hline Taiwan & 1.2 & -1.2 & -0.9 & 2.9 & -2.3 & -2.9 & -4.5 & -2.5 & -14.7 \\
\hline Hong Kong & 6.9 & -1.1 & 0.1 & 15.2 & -3.8 & -3.9 & -14.5 & -5.2 & -23.1 \\
\hline Indonesia & 2.7 & -0.5 & -0.9 & 8.8 & -3.6 & -3.1 & 13.4 & -12.1 & -30.6 \\
\hline Malaysia & 4.2 & 0.5 & -0.9 & 6.9 & -3.3 & -2.9 & 0.3 & -8.2 & -21.3 \\
\hline The Philippines & 1.2 & -1.1 & -0.9 & 2.9 & -2.9 & -2.9 & 8.1 & -7.5 & -27.9 \\
\hline Singapore & 18.2 & -1.6 & -0.9 & 8.9 & -3.5 & -3.0 & 1.9 & -6.7 & -19.6 \\
\hline Thailand & 3.1 & 0.6 & -1.3 & -5.3 & -1.9 & -3.0 & 0.3 & -7.6 & -21.9 \\
\hline China & 36.6 & 18.1 & -1.2 & 132.0 & -10.2 & -2.6 & 245.2 & -27.9 & -31.9 \\
\hline
\end{tabular}

Source: FTAP model projections, partial equilibrium closure.

Notes: $\mathrm{Q}=$ domestic output quantity; $\mathrm{Pd}=$ domestic price; $\mathrm{Pm}=$ import price.

- how the cost (and hence price) of its output changes relative to the average price (across sources) of primary and tertiary output, and how domestic consumers and government substitute between the outputs of these different sectors as a result of these relative price changes; ${ }^{7}$ and

- what the secondary input requirements are per unit of output in other sectors, and whether those other sectors are expanding or contracting.

Thus, even in the partial equilibrium model, the richness of substitution possibilities and interindustry linkages on the demand side make for a rather complicated story.

Because real incomes in each economy are assumed to be fixed, it would be expected that unless substitution effects dominate, the demand for, and hence output of, a commodity or service should increase whenever services trade liberalization reduces its price. And the only sector in which services trade liberalization would conceivably not reduce the price is the primary sector, where the return to the fixed factor could conceivably be bid up. Thus, the presumption is that services trade liberalization should reduce prices and increase output. Where this does not occur, it must be as a result of substitution effects.

Within the services sector itself, prices fall and output rises in the ASEAN economies and China (table 1.3). Note that although the prices of domestic services fall in these economies, the prices of imported services

7. In FTAP, as in GTAP, consumers and government are the only agents to substitute directly among different commodities. For intermediate and investment usage, different commodities (aggregated across sources) are used in fixed proportions. 
fall by significantly more. Thus, substitution toward imports in these economies might suggest that services output should fall. Offsetting this, however, is an increase in exports of services from these economies. In the services sector, the price of a service import in the destination country can fall by significantly more than its output price in the exporting country. This is primarily because services trade liberalization involves removing the "export tax" equivalent of barriers to cross-border trade imposed by the destination country. Thus, although domestic services in the ASEAN region and China are disadvantaged relative to imports at home, when the same services are exported, their prices compare favorably with service exports from most other regions. (This is indicated indirectly by the fact that the domestic output price of services falls by more in ASEAN and China than in the other regions.) Thus, the services output expansion in ASEAN and China is primarily an export story.

In the higher per capita income economies, services output falls, despite a reduction in the domestic price, because of substitution toward imports. This is in accordance with the relative price movements shown in table 1.3.

The declines in the output of the secondary sector in Japan and the United States are because of substitution toward imports, especially in intermediate usage. For the other higher-income economies (Korea, Taiwan, and Hong Kong), the prices of domestic secondary output do not change greatly relative to secondary import prices, so the secondary-output expansions in these economies are primarily an export story. In ASEAN and China, the secondary-output expansions are because of both increased exports and substitution away from imports.

Although in the secondary and tertiary sectors the results are driven primarily by substitution among different sources of each commodity, in the primary sector it is possible to see the effects of each region's households' substituting among different commodities. This explains the slight falls in the output of the primary sector in Japan and Korea. In these economies, the prices of imported services fall significantly more than the prices of any other final commodity. Households tend to substitute toward imported services and away from everything else. Thus, primary output in these economies falls, despite the fact that the price of domestic primary output falls by more than its import price.

In the United States, the effect on primary-sector output of households' switching away from the primary sector in general is reinforced by substitution (in relative terms) toward primary imports.

In Taiwan, Hong Kong, Singapore, and Thailand, the expansion of the primary sector is primarily an export story. (The landed cost plus insurance and freight [c.i.f.] price of Thai primary exports falls, despite a slight increase in the domestic output price, because of cheaper international trade and transport services.) This can be confirmed by looking at more detailed model results not shown in table 1.3. 
In Indonesia, Malaysia, the Philippines, and China, the switch by households away from the primary sector in general is offset by increased intermediate input demand, and some increase in export demand, for primarysector output. The increased intermediate demand occurs despite an adverse relative price movement against imports (in all but the Philippines), because of interindustry linkages between the primary sector and the downstream secondary and tertiary sectors.

In summary, multilateral liberalization of services trade reduces domestic costs and prices across all economies, and the partial equilibrium sectoral effects are of three types.

- In economies such as those of Japan and the United States, where initial domestic services barriers are particularly low, domestic prices do not fall by much, and substitution toward cheaper imports leads to a reduction in output in all sectors of the economy. Real income can remain constant, however, because of the cheaper imports.

- At the other extreme, in the economies of the ASEAN region and China, where initial domestic services barriers are relatively high, domestic prices tend to fall significantly, and output in (almost) all sectors of these economies expands.

- In between are the economies of Korea, Taiwan, and Hong Kong, where initial domestic services barriers are moderate, but where all sectors are more trade exposed than in Japan and the United States. Thus, although the services sectors in these economies may not benefit from services trade liberalization, at least some of their other sectors benefit from cheaper domestic and imported inputs and thus gain an advantage on export markets.

\subsubsection{General Equilibrium Effects on Sectoral Output}

The partial equilibrium results of table 1.3 assumed that each sector in each economy could get any additional labor and capital at the going wage or rental price. The results also ignored the income implications of services trade liberalization.

In table 1.4, these effects are gradually reintroduced into the model. The first column reproduces the partial equilibrium results from table 1.3. In the second column, primary factor supply constraints are imposed. As in textbook models, aggregate supplies of capital and labor are assumed to be fixed, and these factors are treated as being perfectly mobile within each sector of the economy. In the third column, sectoral capital stocks are assumed to take the values they would in the full general equilibrium model. Thus, not only do aggregate capital stocks change in each economy, but capital is no longer perfectly mobile across sectors. Finally, the full general equilibrium results are presented. These incorporate not only the primary factor behavior of the full general equilibrium model, but also the associ- 


\begin{tabular}{|c|c|c|c|c|}
\hline & $\begin{array}{c}\text { Full } \\
\text { Partial } \\
\text { Equilibrium }\end{array}$ & $\begin{array}{l}\text { Fixed } \\
\text { Factors }\end{array}$ & $\begin{array}{l}\text { Capital as in } \\
\text { General } \\
\text { Equilibrium }\end{array}$ & $\begin{array}{c}\text { Full } \\
\text { General } \\
\text { Equilibrium }\end{array}$ \\
\hline \multicolumn{5}{|l|}{ Japan } \\
\hline Primary & -0.3 & 0.2 & -0.3 & -0.4 \\
\hline Secondary & -1.4 & 0.9 & -0.5 & -0.3 \\
\hline Tertiary & -3.4 & -0.3 & 0.2 & 0.1 \\
\hline \multicolumn{5}{|l|}{ United States } \\
\hline Primary & -1.3 & 2.4 & 0.4 & 0.6 \\
\hline Secondary & -7.3 & 1.9 & 0.2 & 0.6 \\
\hline Tertiary & -4.3 & -0.7 & -0.2 & -0.4 \\
\hline \multicolumn{5}{|l|}{ Korea $^{\mathrm{a}}$} \\
\hline Primary & -0.1 & -0.5 & -0.7 & -0.8 \\
\hline Secondary & 2.3 & -0.4 & -1.4 & -1.6 \\
\hline Tertiary & -2.3 & 0.3 & 1.0 & 1.1 \\
\hline \multicolumn{5}{|l|}{ Taiwan $^{\mathrm{a}}$} \\
\hline Primary & 1.2 & 0.4 & -0.1 & 0.1 \\
\hline Secondary & 2.9 & 2.5 & 0.2 & 1.0 \\
\hline Tertiary & -4.5 & -1.1 & 0.1 & -0.2 \\
\hline \multicolumn{5}{|l|}{ Hong Kong ${ }^{\mathrm{a}}$} \\
\hline Primary & 6.9 & 3.7 & 0.0 & 0.2 \\
\hline Secondary & 15.2 & 9.0 & -1.2 & -2.2 \\
\hline Tertiary & -14.5 & -2.1 & 0.4 & 0.6 \\
\hline \multicolumn{5}{|l|}{ Indonesia $^{a}$} \\
\hline Primary & 2.7 & -3.4 & 0.3 & 0.3 \\
\hline Secondary & 8.8 & -9.7 & 2.5 & 2.6 \\
\hline Tertiary & 13.4 & 8.9 & 8.5 & 9.2 \\
\hline \multicolumn{5}{|l|}{ Malaysia $^{\mathrm{a}}$} \\
\hline Primary & 4.2 & -1.1 & 0.0 & 0.1 \\
\hline Secondary & 6.9 & -1.8 & 0.2 & 0.1 \\
\hline Tertiary & 0.3 & 3.3 & 1.5 & 1.5 \\
\hline \multicolumn{5}{|c|}{ The Philippines ${ }^{\mathrm{a}}$} \\
\hline Primary & 1.2 & -3.0 & -1.9 & -1.9 \\
\hline Secondary & 2.9 & -6.6 & -2.6 & -3.6 \\
\hline Tertiary & 8.1 & 5.6 & 2.3 & 2.5 \\
\hline \multicolumn{5}{|l|}{ Singapore } \\
\hline Primary & 18.2 & 3.2 & -4.0 & -4.0 \\
\hline Secondary & 8.9 & -4.2 & -5.6 & -6.6 \\
\hline Tertiary & 1.9 & 4.5 & 0.6 & 1.0 \\
\hline \multicolumn{5}{|l|}{ Thailand $^{\mathrm{a}}$} \\
\hline Primary & 3.1 & 0.7 & -0.2 & -0.1 \\
\hline Secondary & -5.3 & -8.0 & -0.7 & -0.8 \\
\hline Tertiary & 0.3 & 8.1 & 1.3 & 1.3 \\
\hline \multicolumn{5}{|l|}{ China $^{\mathrm{a}}$} \\
\hline Primary & 36.6 & -6.5 & -1.1 & -0.2 \\
\hline Secondary & 132.0 & -16.7 & 4.5 & 2.5 \\
\hline Tertiary & 245.2 & 43.7 & 28.7 & 32.5 \\
\hline
\end{tabular}

Source: FTAP model projections, partial and general equilibrium closures.

${ }^{a}$ Aggregate capital stock projected to increase in general equilibrium closure. 
ated income effects (including the net foreign income flows associated with FDI).

In broad terms, the imposition of factor supply constraints is the single most important step in taking the partial equilibrium sectoral results toward their general equilibrium values.

Even with factor supply constraints, the results for the tertiary sector in each region are qualitatively quite close to the partial equilibrium results:

- the services sectors in Japan and the United States are still smaller than in the absence of services trade liberalization;

- the services sectors in most other high-income economies are also projected to decline (Korea is the exception); and

- the services sectors in the ASEAN region and China still gain from services trade liberalization.

Now, however, the wage-rental ratios in each economy adjust to ensure that the induced output changes in other sectors do not lead to a violation of the overall primary factor supply constraints. Thus, the output of the primary and secondary sectors in Japan, the United States, Taiwan, and Hong Kong is now projected to rise to counteract the decline in their services sectors. In the ASEAN region, China, and Korea, output in many of the primary and secondary sectors is now projected to decline to offset the expansion of their services sectors.

One question is whether the changes in wage-rental ratios in the "fixed factors" version of the model are consistent with those predicted by the Stolper-Samuelson theorem. That theorem would predict that in the face of a decline in the relative price of services (induced by services trade liberalization) there would be a decline in the real return to the factor of production used relatively intensively in the services sector. In most economies, that factor is labor (see figure 1.1). Although the assumption of fixed factor supplies and perfect factor mobility is consistent with the assumptions of the Stolper-Samuelson theorem, there are many other assumptions in the "fixed factors" model that do not match the textbook Stolper-Samuelson assumptions exactly. It is nevertheless useful to see if the "fixed factors" model retains a Stolper-Samuelson flavor in the context of services trade liberalization.

Broadly speaking, the Stolper-Samuelson theorem would predict a decline in the wage-rental ratio in most economies; by contrast, the wagerental ratio faced by producers in all economies in the "fixed factors" model is projected to rise. The reason is simple. Services trade liberalization includes liberalization of FDI in the services sector. The removal of taxes on service-sector capital leads to a direct and significant decline in capital rentals, relative to wages, because, with fixed capital supplies, the loss of rents from barriers to capital are borne directly by capital owners. ${ }^{8}$

8. The implication of this for regional incomes is not yet incorporated. 
Thus, the nature of barriers to services trade leads to a significant departure from one of the standard textbook trade theorems. ${ }^{9}$

The results in the third column hint at the complexity of the capital supply story in the full FTAP model. Even though services trade liberalization involves removing taxes on service-sector capital, it is not always the case that cautious investors would invest more in those service sectors than they would if they viewed investment in any sector as being equally desirable (consistent with perfect sectoral capital mobility). In Japan, the United States, Korea, Taiwan, and Hong Kong, service-sector capital stocks are larger than in the "fixed factors" case, but in the other economies they are smaller. This demonstrates how the capital supply behavior in the FTAP model plays an important role in relocating capital across regions within a sector, as opposed to the textbook treatment of capital allocation across sectors within a region.

One question is whether the sectoral output responses associated with a change in aggregate capital stocks are consistent with those predicted by the Rybczynski theorem. That theorem states that if product prices are fixed (say, by "world prices"), an expansion in capital would lead to an expansion in the output of the product that uses capital relatively intensively and a contraction of the other product. Leamer and Levinsohn $(1994,7)$ give an insightful reinterpretation of the Rybczynski theorem:

What is really at stake here is not the Rybczynski Theorem but rather its traveling companion, the Factor Price Equalization Theorem. These results together imply that factor supply changes ... do not have much affect [sic] on factor prices because the potential affect [sic] on factor prices is dissipated by product mix changes in favor of the products that use the accumulating factor intensively.

Clearly, critical assumptions of the Rybczynski Theorem do not hold in the FTAP model. Products are imperfect substitutes, so that product prices are not "given" to any single region. As a result, relative factor prices can also change to absorb the impact of an increase in capital, so that it does not have to be absorbed by changes in product composition.

However, one would expect the FTAP model to display the same underlying economic forces that lead to the Rybczynski result under its special set of assumptions. This can be demonstrated in an intermediate simulation in which aggregate capital in each region moves as it does in general equilibrium but is still perfectly mobile between sectors (thus, each region still has a unique economy-wide wage-rental ratio). In this intermediate simulation,

9. The particular result depends on the assumption that barriers to trade in services create rents rather than raising costs. If barriers to services trade raise costs and hence move the production possibility frontier toward the origin, then services trade liberalization could raise the real returns to all factors of production, although the effects on relative factor returns could still be unclear a priori. Brown, Deardorff, and Stern (2000) also show how real returns to both factors can be raised by the additional gains from trade arising from increasing returns to scale, competition, and product variety, even when barriers are treated as tariff equivalents. 
there is the expected relationship between the direction of movement of the capital stock and whether the wage-rental ratio is higher or lower than in the "fixed factors" version of the model. When the capital stock rises, the wage-rental ratio is higher than in the "fixed factors" case, and when the capital stock falls, the wage-rental ratio is lower.

The final column of table 1.4 incorporates the FTAP model's income linkages: real income in each region is no longer constant but reflects the induced changes in factor prices and international capital movements. Dee and Hanslow (2000) demonstrate that such income effects are crucial to the welfare implications of liberalizing trade in services, as will be seen shortly. However, table 1.4 shows that these income effects do not have strong additional effects on the sectoral distribution of gains from services trade liberalization.

General equilibrium models are often regarded as "black boxes," offering little chance of understanding what is inside. The above analysis suggests that because the structure of barriers to services trade is complex, the hardest part about understanding the effects of multilateral liberalization of services trade is understanding what happens in partial equilibrium.

The partial equilibrium results help to demonstrate how liberalization of services trade can differ from tariff removal. Barriers to services trade affect domestic new entrants as well as foreign suppliers, and the sector to benefit most in output terms from liberalization can often be the services sector itself.

The transition from partial to general equilibrium analysis also demonstrates how some of the standard textbook results fail to hold in the context of services trade liberalization. In particular, because services trade barriers affect the price of service-sector capital as well as service-sector output, the Stolper-Samuelson theorem fails to hold: the movement of relative factor prices is dominated by the removal of the barriers to capital movement. The Rybczynski theorem also fails to hold in its textbook form, but the underlying economic forces that lead to its result are still relevant.

\subsubsection{General Equilibrium Welfare Effects}

The first column of table 1.5 summarizes the effects of full liberalization of services trade on economic well-being in selected model regions (Dee and Hanslow [2000] present results for all model regions). As in GTAP, the measure of economic well-being is the equivalent variation - essentially a measure of the change in real income in each region, where the deflator is an index of the prices of household consumption, government consumption, and national saving. For FTAP, however, the relevant measure of national income is net national product - the income accruing to the residents of a region - rather than net domestic product - the income generated within the borders of a region. Thus, net domestic product is adjusted for the income earned on outward FDI, net of the income repatriated overseas from inward FDI, plus the income from net bond holdings. 


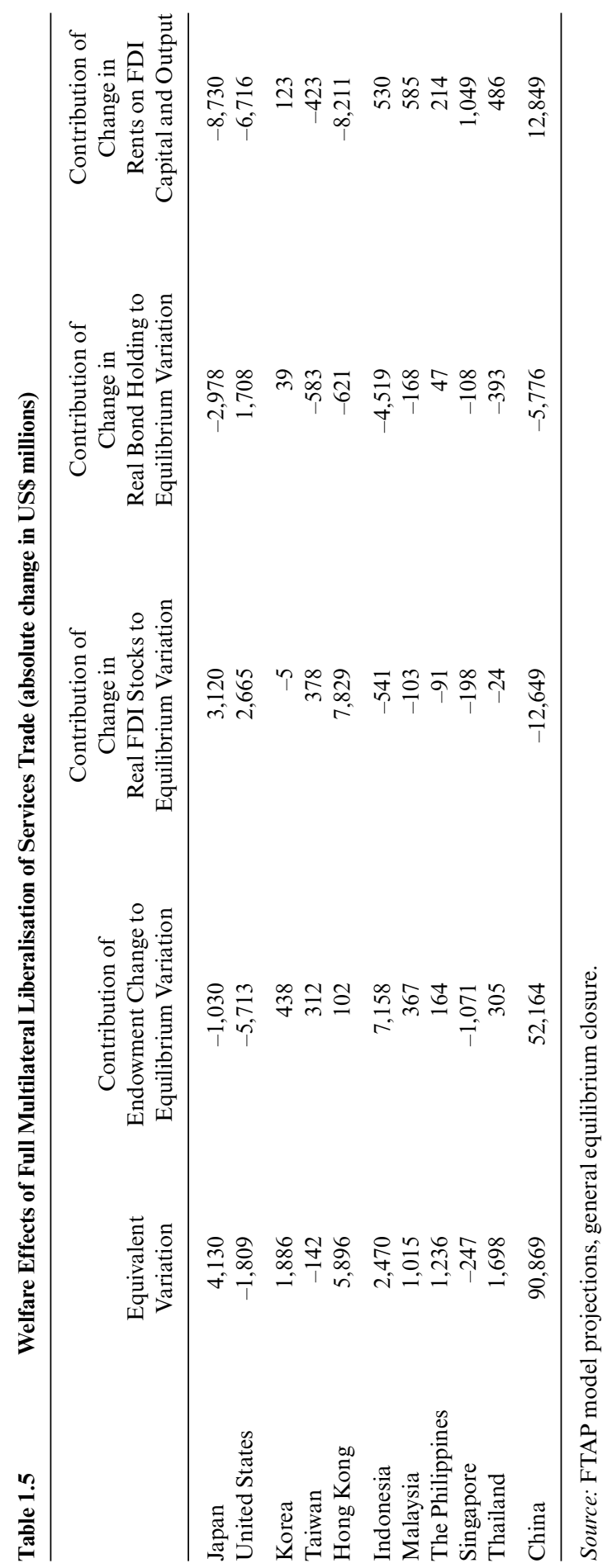


Three of the selected economies are projected to have incomes lower than otherwise as a result of full multilateral liberalization of services trade - the United States, Taiwan, and Singapore. Dee and Hanslow (2000) show that in each case, the losses from multilateral liberalization of services trade would be more than offset by income gains accruing from multilateral liberalization of trade in agriculture and manufacturing. Nevertheless, the source of the income losses from multilateral liberalization of services trade warrants further investigation, especially for the United States, where the losses are projected to be significant.

Dee and Hanslow show that for agricultural and manufacturing liberalization, the welfare results are dominated by two things: the contribution of improvements in allocative efficiency, and the contribution of induced changes in the terms of trade. The model's regions are projected to experience positive income gains, or in a few cases small losses, as a result of these effects.

For services liberalization, changes in FDI patterns contribute several additional effects. First, FDI can lead to an expansion or contraction in the capital stock located within a region, leading to a positive or negative contribution to income generated within a region from this change in national endowments. Second, it can lead to changes in net FDI and net lending positions, with consequent changes in net foreign income flows accruing to residents. Third, it can induce changes in the returns earned on those net foreign asset holdings. An important example here is changes in the rents earned on FDI.

The second column of table 1.5 shows the contribution to real income from changes in real capital endowments. Generally, if capital endowments are higher than otherwise, real GDP will be higher than otherwise, and vice versa. ${ }^{10} \mathrm{~A}$ major reason that Singapore is projected to lose slightly from services trade liberalization is that its capital stock is projected to be lower than otherwise.

However, a lower capital stock located domestically need not always lead to lower incomes for domestic residents. Earnings from higher outward FDI and higher lending abroad could offset it. The third column of table 1.5 shows the contribution to residents' real income from changes in real FDI stocks. The fourth column shows the contribution from changes in real bond holdings. Both also help to indicate the way in which changes in capital endowments are financed.

For example, Japan's capital stock is lower than otherwise, but it has a big increase in outward FDI. In fact, it also borrows (a negative change in bond holding) in order to finance its outward FDI. By contrast, China's increase in capital endowments comes partly from a large increase in inward FDI

10. For a few regions, real GDP can be higher than otherwise, even if endowments are lower than otherwise, because the endowments are used more efficiently. 
and partly from additional foreign borrowing. Thus, the large projected increase in China's service-sector output and exports, noted above, comes as much from an expansion in foreign-owned service firms located in China as it does from an expansion in Chinese-owned service firms. The United States is projected to have a smaller capital endowment than otherwise, but this is offset to some extent by an increase in outward FDI and increased lending to other regions.

For a few regions, real incomes are affected not so much by changes in net asset positions, but by changes in returns on those assets. Although the details are not shown in table 1.5, Taiwan is projected to lose slightly from services trade liberalization, primarily because in the FTAP database it is a net creditor economy and is adversely affected by a small induced fall in real interest rates. ${ }^{11}$

A further source of change in asset returns is the change in rents generated by barriers to services trade. The last column of table 1.5 shows the income contribution to recipient countries of changes in the rents accruing to FDI, as barriers to services trade are eliminated. What is striking is the loss of rents to the main providers of outward FDI_-Japan, Hong Kong, and the United States. In fact, the loss of rents to U.S. incumbent multinationals is more than sufficient to explain its overall projected income loss from multilateral liberalization of services trade. Note, however, that this result is sensitive to the assumption that all barriers to services trade are rentcreating rather than cost-raising. ${ }^{12}$

Generally, although induced changes in capital stocks - both those located domestically and those owned abroad - do not appear to play a major role in explaining the effects of multilateral services trade liberalization on sectoral output, they play a major role in explaining the effects on real regional incomes. Barriers to services trade affect capital movements as well as the output of services firms, so services trade liberalization can have a significant effect on the regional location and ownership of capital. The flow-on effects to regional incomes demonstrate another way in which liberalization of services trade can differ from tariff removal.

\subsection{Agenda for Further Research}

Much of the research agenda for further development of the FTAP model has been outlined already. It involves continuing to obtain estimates of the price impacts of barriers to services trade along the lines outlined in

11. Interest rates fall primarily because of an assumption that government saving rates are held constant. Growing revenues and saving levels, therefore, allow some government debt retirement.

12. Brown, Deardorff, and Stern (2000) show that if barriers are cost-escalating, then welfare effects are dominated by the movement of real physical capital. However, they have a more simple treatment of profit repatriation and debt service payments than here. 
Findlay and Warren (2000), both for additional sectors and for additional modes of service delivery within a sector. The methodologies should in the process reveal whether the barriers are rent-creating or cost-raising. Such methods could also be used to estimate the price impact of barriers to FDI in agriculture and manufacturing. More sectoral detail needs to be incorporated into FTAP, to model the barriers to each service separately. More research is required to obtain more realistic output estimates and cost and sales structures for FDI firms and, if possible, a realistic initial allocation of rents. Additionally, the welfare measure in FTAP needs to be amended to take account of the costs of risk taking, given risk aversion.

In addition, some of the simplifying assumptions made during the original development of FTAP could now be relaxed, and the sensitivity of the results to these assumptions tested. One such assumption was the uniformity of behavioral parameters across sectors and regions. Although this reflected a deliberate research strategy, its importance could be tested using systematic sensitivity analysis (Arndt and Pearson 1996). The importance of data issues (e.g., the initial distribution of rents) and theoretical issues (e.g., investor behavior) could also be explored.

However, there is also scope for much more work using simple analytical models of services trade that better incorporate the features of services and the nature of the barriers to their trade. Insights of the sort available in Markusen, Rutherford, and Hunter (1995), for example, provide invaluable guidance to those attempting to build better empirical models of FDI and services trade.

\section{References}

Arndt, C., and K. Pearson. 1996. How to carry out systematic sensitivity analysis via Gaussian Quadrature and GEMPACK. GTAP Technical Paper no. 3. Purdue University: Center for Global Trade Analysis.

Asia-Pacific Economic Cooperation (APEC). 1995. Foreign direct investment and APEC economic integration. Singapore: APEC Economic Committee.

Baldwin, R. E., and F. Kimura. 1998. Measuring U.S. international goods and services transactions. In Geography and ownership as bases for economic accounting, ed. R. E. Baldwin, R. Lipsey, and J. D. Richardson, 9-48. Chicago: University of Chicago Press.

Brown, D. K., A. V. Deardorff, A. K. Fox, and R. M. Stern. 1995. Computational analysis of goods and services liberalization in the Uruguay Round. In The Uruguay Round and the developing economies, ed. W. Martin and L. A. Winters, 365-80. Washington, D.C.: World Bank.

Brown, D., A. Deardorff, and R. Stern. 1996. Modeling multilateral trade liberalization in services. Asia Pacific Economic Review 2 (1): 21-34.

. 2000. CGE modeling and analysis of multilateral and regional negotiating options. Paper presented at conference on Issues and Options for the Multilat- 
eral, Regional, and Bilateral Trade Policies of the United States and Japan. 5-6 October, University of Michigan.

Brown, D., and R. Stern. 2001. Measurement and modeling of the economic effects of trade and investment barriers in services. Review of International Economics 9 (2): 262-86.

Deardorff, A. 1985. Comparative advantage and international trade and investment in services. In Trade and investment in services: Canada/U.S. Perspectives, ed. R. Stern, 39-71. Toronto, Canada: Ontario Economic Council.

Dee, P., C. Geisler, and G. Watts. 1996. The impact of APEC's free trade commitment. Industry Commission Staff Information Paper. Canberra, Australia: Australian Government Publishing Service, February.

Dee, P., and K. Hanslow. 2000. Multilateral liberalization of services trade. Productivity Commission Staff Research Paper. Canberra, Australia: Ausinfo.

Dee, P., A. Hardin, and M. Schuele. 1998. APEC early voluntary sectoral liberalization. Productivity Commission Staff Research Paper. Canberra, Australia: Ausinfo.

Findlay, C., and T. Warren, eds. 2000. Impediments to trade in services: Measurement and policy implications. London: Routledge.

Francois, J. F., B. McDonald, and H. Nordstrom. 1995. Assessing the Uruguay Round. In The Uruguay Round and the developing economies, ed. W. Martin and L. A. Winters, 117-214. Washington, D.C.: World Bank.

Gehlhar, M. 1997. Historical analysis of growth and trade patterns in the Pacific Rim: An evaluation of the GTAP framework. In Global Trade Analysis: Modelling and Applications, ed. T. Hertel, 349-63. Cambridge: Cambridge University Press.

Grossman, G., and E. Helpman. 1991. Innovation and growth in the global economy. Cambridge: Massachusetts Institute of Technology Press.

Hanslow, K., T. Phamduc, and G. Verikios. 1999. The structure of the FTAP model. Productivity Commission, Canberra. Research Memorandum, December.

Hanslow, K., T. Phamduc, G. Verikios, and A. Welsh. 2000. Incorporating barriers to FDI into the FTAP database. Productivity Commission, Canberra. Research Memorandum.

Harrison, J. W., and K. R. Pearson. 1996. Computing solutions for large general equilibrium models using GEMPACK. Computational Economics 9 (2): 83-127.

Heckscher, E. [1919] 1949. The effect of foreign trade on the distribution of income. Reprinted in Readings in the theory of international trade, ed. American Economic Association. Philadelphia, Blakiston.

Helpman, E. 1981. International trade in the presence of product differentiation, economies of scale, and monopolistic competition: A Chamberlinian-HeckscherOhlin approach. Journal of International Economics 11:304-40.

Hertel, T. 1997. Global trade analysis: Modeling and applications. Cambridge: Cambridge University Press.

Hertel, T. 1999. Potential gains from reducing trade barriers in manufacturing, services, and agriculture. Paper presented at the 24th Annual Economic Policy Conference, Federal Reserve Bank of St. Louis. 21-22 October, St. Louis, Miss.

Hindley, B., and A. Smith. 1984. Comparative advantage and trade in services. World Economy 7:369-90.

Hoekman, B. 1995. Assessing the general agreement on trade in services. In The Uruguay round and the developing economies, ed. W. Martin and L. A. Winters, 327-64. Washington, D.C.: World Bank.

Johnson, M., T. Gregan, G. Gentle, and P. Belin. 2000. Modeling the benefits of increasing competition in international air services. In Impediments to trade in services: Measurement and policy implications, ed. C. Findlay and T. Warren, 119-51. London: Routledge. 
Jones, R., and J. Scheinkman. 1977. The relevance of the two-sector production model in trade theory. Journal of Political Economy 85 (5): 909-35.

Kaleeswaran, K., G. McGuire, D. Nguyen-Hong, and M. Schuele. 2000. The price impact of restrictions on banking services. In Impediments to trade in services: Measurement and policy implications, ed. C. Findlay and T. Warren, 215-30. London: Routledge.

Kimura, F., and R. E. Baldwin. 1998. Application of a nationality-adjusted net sales and value-added framework: The case of Japan. In Geography and ownership as bases for economic accounting, ed. R. E. Baldwin, R. Lipsey, and J. D. Richardson, 49-82. Chicago: University of Chicago Press.

Krugman, P. 1979. Increasing returns, monopolistic competition, and international trade. Journal of International Economics 9:469-79.

Leamer, E., and J. Levinsohn. 1994. International trade theory: The evidence. NBER Working Paper no. 4940. Cambridge, Mass.: National Bureau of Economic Research, November.

Liu, J., C. Arndt, and T. Hertel. 2000. Estimating trade elasticities for GTAP: A maximum entropy approach. Paper presented at the Third Annual Conference in Global Economic Analysis. 26-29 June, Melbourne, Australia.

Malcolm, G. 1998. Adjusting tax rates in the GTAP data base. GTAP Technical Paper no. 12. Purdue University, Center for Global Trade Analysis.

Markusen, J. 1981. Trade and the gains from trade with imperfect competition. Journal of International Economics 11:531-51.

1989. Trade in producer services and in other specialized intermediate inputs. American Economic Review 79 (1): 85-95.

Markusen, J., T. Rutherford, and L. Hunter. 1995. Trade liberalization in a multinational dominated industry. Journal of International Economics 38 (1-2): 95117.

Markusen, J., T. F. Rutherford, and D. Tarr. 1999. Foreign direct investment in services and the domestic market for expertise. Paper presented at the Second Annual Conference on Global Economic Analysis. 20-22 June, Denmark.

Mayer, W. 1974. Short-run and long-run equilibrium for a small open economy. Journal of Political Economy 82:955-68.

McDougall, R. 1993. Incorporating international capital mobility into SALTER. SALTER Working Paper no. 21. Industry Commission, Canberra, Australia.

Melvin, J. 1969. Increasing returns to scale as a determinant of trade. Canadian Journal of Economics 2:389-402.

1989. Trade in producer services: A Heckscher-Ohlin approach. Journal of Political Economy 97 (5): 1180-96.

Mussa, M. 1974. Tariffs and the distribution of income: The importance of factor specificity, substitutability, and intensity in the short and long run. Journal of Political Economy 82:1191-204.

Nagarajan, N. 1999. The millennium round: An economic appraisal. Economic Papers no. 139. Directorate General for Economic and Financial Affairs, European Commission, November.

Ohlin, B. 1933. Interregional and international trade. Cambridge, Mass.: Harvard University Press.

Petri, P. A. 1997. Foreign direct investment in a computable general equilibrium framework. Paper prepared for the conference on Making APEC Work: Economic Challenges and Policy Alternatives. 13-14 March, Keio University, Tokyo, Japan.

Rybczynski, T. 1955. Factor endowment and relative commodity prices. Economica 22:336-41. 
Stolper, W., and P. Samuelson. 1941. Protection and real wages. Review of Economic Studies 9:58-73.

United Nations. 1994. World investment directory: Latin America and the Caribbean. New York: United Nations.

Verikios, G., and K. Hanslow. 1999. Modeling the effects of implementing the Uruguay Round: A comparison using the GTAP model under alternative treatments of international capital mobility. Paper presented at the Second Annual Conference on Global Economic Analysis. 20-22 June, Denmark.

Warren, T. 2000. The impact on output of impediments to trade and investment in telecommunications services. In Impediments to trade in services: Measurement and policy implications, ed. C. Findlay and T. Warren, 85-100. London: Routledge.

Welsh, A., and A. Strzelecki. 2000. Estimating domestic and foreign returns to capital for the FTAP model. Productivity Commission, Melbourne, Australia. Research Memorandum, May.

\section{Comment Fukunari Kimura}

The research group of the Productivity Commission of Australia has conducted a series of great effort in quantifying the economic effects of liberalizing trade in services and has contributed to constructive discussion in a number of international academic and semi-academic forums. Admittedly, it is not at all easy to measure the magnitude of barriers to services trade as well as formulating a reasonable policy simulation model with rigorous theoretical framework. Nevertheless, it is crucially important to quantify possible effects of trade liberalization in order for policy makers to carry on a constructive discussion resisting various politico-economic pressures. The current paper presents a step forward in taking care of some of the features unique to trade in services vis-à-vis trade in goods.

\section{Modes of Services Transactions}

One of the novel features of this paper is the introduction of explicit treatment for modes of services transactions. The General Agreement on Trade in Services (GATS) of the Marrakesh Agreement defines four modes of services transactions: cross-border, consumption abroad, commercial presence, and natural persons. The past literature has tried to construct simulation models with a structure analogous to that for merchandise trade, but those models could only deal with the first mode, cross-border. The other three modes of services transactions require more sophisticated formulations in terms of factor movements across the national border, the place where factor services are inputted, and the nature of corresponding trade barriers. 
The paper particularly puts emphasis on the most important mode of services transactions, that is, commercial presence. Service provision in this mode is initiated from the establishment of a local affiliate or a local branch through international capital movement (typically foreign direct investment [FDI]), and then services are produced in combination with local resources such as labor. The model traces the service supply structure by introducing international capital movement. Furthermore, the model distinguishes two types of barriers to services trade: barriers to establishing commercial presence and barriers to ongoing operation. These two roughly correspond to the concept of market access and national treatment in the table of concession of GATS. The former is modeled as taxes on the movement of capital, and the latter is formalized as taxes on the output of the service-providing firms.

Of course, the statistical measurement of such barriers, as well as the quantification of international capital movement, is not at all easy, and thus simulation results must be regarded as provisionary. However, the pioneering treatment of mode- 3 service transactions will surely become a starting point to formalize services trade in future research.

\section{Handling Capital}

The authors call their model FTAP as a special version of GTAP with FDI. Foreign direct investment is different from simple international capital movements such as portfolio investment in an important way: it is accompanied by the movements of firm-specific assets such as technology and managerial know-how. Particularly in less developed economies, affiliates of foreign firms behave quite differently from local indigenous firms in terms of technology, managerial know-how, the pattern of purchases and sales, and the degree of exposure to foreign markets. Therefore, to seriously model FDI, we prefer to distinguish capital by the owner's nationality in addition to the location where capital services are used. ${ }^{1}$

Such expansion of dimension in policy simulation models raises a number of issues to be solved. One issue is the availability of statistical data. The pioneering work by Petri (1997) as well as that of Dee, Hanslow, and Phamduc basically relies on FDI flow data in estimating the magnitude of activities of affiliates of multinational enterprises (MNEs). However, we have a number of problems in this approach to data construction. First of all, we are not sure whether FDI data properly include reinvestment from retained earnings by affiliates abroad. The treatment of joint ventures is another problem. Moreover, the available figures are for investment flows, and thus we need uneasy transformation from flow to stock. After all, we have only capital stock estimates, which may not be a good proxy for the magnitude

1. See Baldwin and Kimura (1998) on the more detailed discussion on ownership, control, and location when considering FDI. 
of activities of affiliates. We actually have some fragmental but direct information on activities of affiliates of MNEs. The Department of Commerce of the U.S. Government and the Ministry of International Trade and Industry (renamed the Ministry of Economy, Trade, and Industry in January 2001) of the Japanese Government, for example, compile ample activity data on U.S. and Japanese affiliates abroad. Some hosting countries such as Singapore and Malaysia include firm-nationality information in manufacturing censuses. Such information must be utilized to improve the quality of activity data in future research.

Another fundamental issue is the conceptual framework with which to introduce firm-specific assets in theoretically consistent models. ${ }^{2}$ This paper makes an important contribution to the literature on this matter. In the model, investors first divide their wealth between "bonds" and "real physical capital," and then the former go to foreign portfolio investment with perfect arbitrage while the latter proceed to domestic physical investment and FDI with imperfect substitution. This treatment allows the introduction of firm-nationality-specific physical capital.

The paper includes an interesting discussion on the nesting structure of commodity demand. Petri (1997) sets the ownership of producers as a higher nest and then goes down to the location of producers as a lower-rank nest. In contrast, the present paper works with the opposite order. The former formulation is attractive if we think much of the existence of firmspecific assets. For instance, VCRs produced in a Sony plant located in Malaysia are closer substitutes for Japanese-made VCRs in Japan than they are for VCRs produced in a local indigenous plant located in Malaysia. Dee, Hanslow, and Phamduc, however, claim that services must meet local tastes and requirements and thus the location of production should come earlier than the nationality of producers. We obviously need more discussion on how to formulate the nationality of firms and the location of production.

\section{Welfare Effects}

The paper displays the simulation results of removing barriers to trade in services in a step-by-step, intuitive manner by starting from partial equilibrium effects and then explaining general equilibrium effects. The partial equilibrium results in which factor prices as well as domestic factor supplies are fixed look reasonable; with the removal of barriers to trade in services, countries originally with high barriers will gain the most, and those with low barriers will get hurt. Then factor prices are endogenously adjusted, and international capital movements are allowed in the general equilibrium, where the welfare gains are spread out to most of the countries. 
Some uneasy results, particularly the negative welfare effects on the U.S. economy in the general equilibrium setting, should not be worried about too much. Rather, we must realize that the setting for FDI is crucially important in estimating the liberalization effects. If, for example, the U.S. service providers are more competitive than Japanese ones, the pattern of FDI may drastically change, resulting in different welfare impacts across countries. Firm-specific or firm-nationality-specific assets can also be a source of market power, which the symmetric constant elasticity of substitution (CES) nesting of product differentiation may not properly capture. Again, the key issue is how to formulate MNEs in simulation models.

\section{Concluding Remarks}

In summary, this paper makes a big step forward toward quantifying the cost of barriers to trade in services, which is crucially important in setting up a constructive policy discussion. The simulation results, however, have not reached the level of attracting very serious consideration from the nonacademic circle. A major task will be determining how to formulate MNEs in theoretically rigorous models. Although the paper makes a significant contribution to this subject, we have a number of things to settle in the future from both theoretical and empirical points of view. Another important task for us is to make primary statistical data collection of good quality. As for the FDI-related data, the best way to capture the activities of affiliates of MNEs is to collect information in the framework of host countries' establishment or firm censuses. Physical activities are, after all, much easier to capture than flows of financial transactions. As for service transactions, the balance-of-payments statistics cover only a small portion of trade in services. We must develop a statistical framework to capture various aspects of services trade covering four modes and possibly service contents in merchandise trade.

\section{References}

Baldwin, Robert E., and Fukunari Kimura. 1998. Measuring U.S. international goods and services transactions. In Geography and ownership as bases for economic accounting, ed. R. E. Baldwin, R. E. Lipsey, and J. D. Richardson, 9-36. Chicago: University of Chicago Press.

Kimura, Fukunari, and Masahiko Tsutsumi. 1998. The CGE modeling strategies with the nationalities of firms. Paper prepared for the conference Making APEC Work: Economic Challenges and Policy Alternatives. 13-14 March, Keio University, Tokyo, Japan.

Petri, P. A. 1997. Foreign direct investment in a computable general equilibrium framework. Paper prepared for the conference Making APEC Work: Economic Challenges and Policy Alternatives. 13-14 March, Keio University, Tokyo, Japan. 